\title{
A study on the Path of Internationalization Transformation and Development of Higher Education Under the Strategy of "Belt and Road"
}

\author{
Zhouzhou Zhang ${ }^{1}$ \\ Nantong University
}

\author{
Yue Chen ${ }^{2}$ \\ Nantong University
}

\begin{abstract}
Historically, the internationalization of higher education in China has formed a development path based on the western paradigm, with individualized elements as the content and colleges as the centre. Belt and Road's strategy not only challenges the traditional path of internationalization of higher education in China, but also provides an opportunity for transformation and upgrading. In the future, the internationalization of higher education in China should take account of western experience and local experiment on the multipolar territory of east and west, take the mission of helping to carry behaviour, take systematic elements as the content, and take the society as the centre of development. The national conditions and cultural traditions of the countries along the route of "Belt and Road" differ greatly, which requires higher education. In the process of internationalization, we should pay more attention to the local experience, and Belt and Road hopes to form a new region full of vitality and creativity, which provides a new impetus for the emergence of a new generation of "higher education centre". In view of this, based on the tradition of internationalization of higher education in China and the opportunity provided by Belt and Road, this paper expounds the general trend of internationalization of higher education in China in the future, and probes into the path of transformation and development.
\end{abstract}

\section{Keywords}

Belt and Road • Higher Education • Internationalization • Transformation and Upgrading

\footnotetext{
${ }^{1}$ Correspondence to: Zhouzhou Zhang $(\mathrm{PhD})$, Nantong University, Nantong 226001, China. Email: zzzcqq1988@ntu.edu.cn

${ }^{2}$ Nantong University, Nantong 226001, China. Email: zzzcqq1988@ntu.edu.cn
}

Citation: Zhang, Z.Z., Chen, Y. (2018). A study on the Path of Internationalization Transformation and Development of Higher Education Under the Strategy of "Belt and Road". Educational Sciences: Theory \& Practice, 18(5), 2363-2372. http://dx.doi.org/10.12738/estp.2018.5.135 
"Belt and Road" refers to the Silk Road Economic Belt and the 21st Century Maritime Silk Road. In March 2015, the National Development and Reform Commission and other departments issued the Vision and Action to promote the Construction of the Silk Road Economic Belt and the 21st Century Maritime Silk Road, It is further clear that "building a community of interests, destiny and responsibility with political mutual trust, economic integration, cultural inclusion" is the development goal, and forms a new pattern of China's alldirectional opening to the outside world 4.0. (Kang, 2008) The promotion of "Belt and Road" has adapted to the trend of economic globalization and multipolarization of the world, and has met the common needs of countries and regions along the route. The countries along the route complement each other, open up and cooperate with each other and offer a new stage for international cooperation.

The internationalization of higher education is one of the three core concepts of the development of modern higher education put forward by UNESCO in the 1980s, and it is also one of the core strategies of the development of higher education in various countries. However, there are significant differences in identity, function and benefit-sharing between developed and developing countries, and the entire international ecology is still dominated and controlled by developed countries. (Philip \& Atbach, 2006) this process alienates crossculture, the original meaning of internationalization which combines cross-border concept with individual practice may damage the development of a country's higher education and even erode the sovereignty of a country's higher education. As a back hair in our country, the development mode of higher education in our country must go through a process of transition from late exogenous to late endogenous and then to preemptive endogeny. (Liu, 2012) in this process, the structure of production factors within higher education must also be reorganized. (Wu \& Hong, 2013) accordingly, the mission of higher education will also be reconstructed. Undoubtedly, it is urgent to adjust the internationalization mission and its elements of higher education. "shock-reaction" is a logic of the development of higher education in China. (Philip \& Atbach, 2006) Belt and Road, as a "shock" element, provides an unprecedented opportunity for the development of higher education in China. "advocated by Belt and Road" The idea of "Community", "the concept of five links", coincides with the ideal of reciprocity in the internationalization of higher education; The social and economic development of the countries along the route of "Belt and Road" and the improvement of the higher education level need a broader market, which provides an opportunity for the element sublimation and mode transformation of the internationalization of higher education.

\section{The Choice of internationalization path of higher Education under the Strategic background of "Belt and Road"}

According to Jane, a professor at the University of Toronto, Canada. Knight (Xu \& Huang, 2016) (Knight.J) University internationalization Strategy Framework, the internationalization of higher vocational education can be implemented from four aspects: activity path, ability path, reason path, process path and so on. Running Mechanism of M (Management Alliance), in Management Alliance O (Operation Mechanism), Support service S (Support e-Service), talent training $\mathrm{T}$ (Talent Development), as shown in figure 1, to promote our "out of" "to" and the strategic upgrade of opening to the outside world 4.0. 


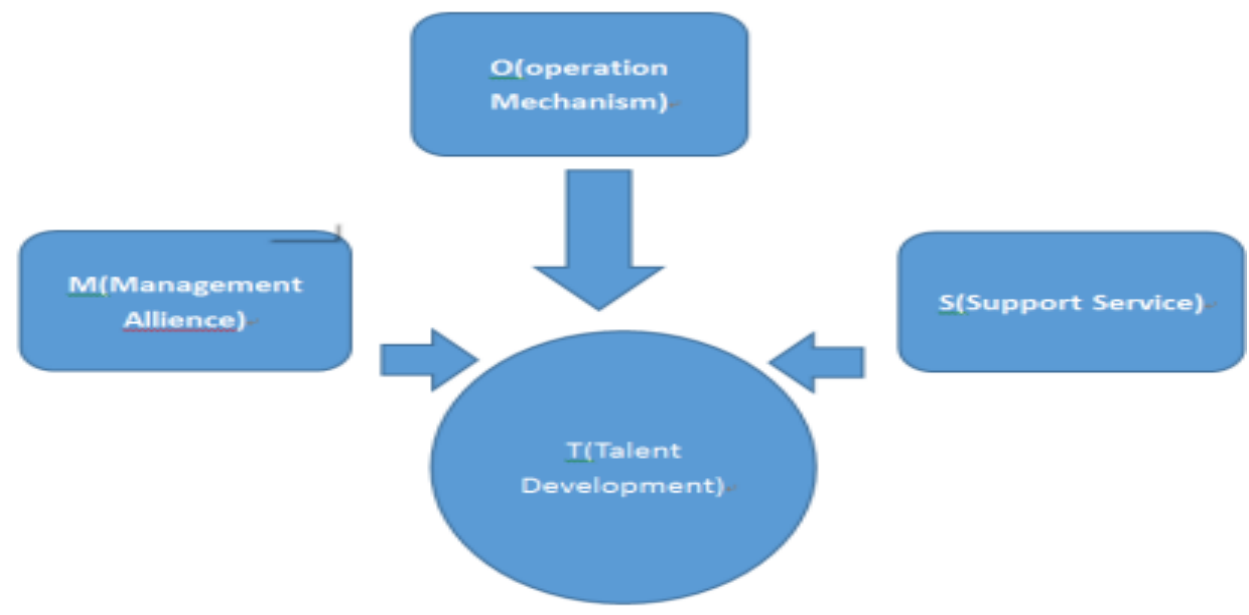

Figure 1. Choice of internationalization path for higher education.

\section{Theoretical basis and background of internationalization of higher Education}

Higher education plays an increasingly important role in the process of globalization. To understand the internationalization of higher education, the core is to pay attention to the cause of internationalization. "if internationalization does not have a clear set of motivations, without a set of goals and accompanying policies, planning, monitoring and evaluation systems, it will be a great deal," says Jane Knight, a leading international expert in higher education. Mixed international opportunities in a fragmented, temporary, simple response. In 1997, Jane Knight and his mentor Hans Di Witt put forward the four-dimensional motivation theory of internationalization of higher education. The theory holds that the internationalization of higher education comes from four aspects: politics, economy, society and culture.

Table 1

Partial data of China's International Contribution 1950-2016

\begin{tabular}{|c|c|c|c|c|c|c|}
\hline $\begin{array}{l}\text { Cumulative } \\
\text { external } \\
\text { assistance }\end{array}$ & $\begin{array}{l}\text { Implementation } \\
\text { of various } \\
\text { foreign aid } \\
\text { projects }\end{array}$ & $\begin{array}{l}\text { Training of } \\
\text { various } \\
\text { categories of } \\
\text { personnel in } \\
\text { China for } \\
\text { developing } \\
\text { countries } \\
\end{array}$ & $\begin{array}{c}\text { Cumulative } \\
\text { attraction of } \\
\text { foreign } \\
\text { investment }\end{array}$ & $\begin{array}{l}\text { Cumulative } \\
\text { outward } \\
\text { direct } \\
\text { investment }\end{array}$ & $\begin{array}{c}\text { The } \\
\text { proportion of } \\
\text { China's } \\
\text { economy in } \\
\text { the world } \\
\text { economy in } \\
2016 \\
\end{array}$ & $\begin{array}{l}\text { Contribution } \\
\text { of } 2016 \text { to } \\
\text { world } \\
\text { economic } \\
\text { growth }\end{array}$ \\
\hline $\begin{array}{l}\text { Over } 400 \\
\text { billion } \\
\text { (RMB) }\end{array}$ & More than 5000 & $\begin{array}{l}\text { More than } \\
260000\end{array}$ & $\$ 1.7$ trillion & $\$ 1.2$ trillion & $16.48 \%$ & $30 \%$ \\
\hline
\end{tabular}

Since the 21 st century, the global flow of production factors, the gradual expansion of the world market, and the establishment and gradual improvement of the global governance system have resulted in the disappearance of the globalization pattern led by the United States, and the developing countries represented by China. The emergence of a group of emerging market countries, such as the BRICS, is changing the balance of international power, and the trend of world multipolarization is becoming increasingly evident, 
Zhang, Chen / A study on the Path of internationalization Transformation and Development...

forming a community of human destinies (Qin \& Xia, 2016). In particular, with the development of China in the past 40 years since the reform and opening up, the economy, science and technology and other comprehensive national strength have increased significantly, and have moved from the edge of the world stage to the center of the world stage. Is highly recognized by the international community, as shown in table 1.

\section{Strategic significance of internationalization of higher Education}

Internationalization is the trend of the development of higher education in the world. More and more countries realize that education reform and development must be examined from a global perspective, and the international flow of educational resources is also happening consciously and open and inclusive. Cooperation and complementarity have become the common choice of universities in various countries. The internationalization of higher education has gone beyond the level of educational policy and has become a national development strategy (Deng, Zhang \& Li, 2015).

Table 2

Number of American Students Studying in the United States

\begin{tabular}{lcccc}
\hline $\begin{array}{l}\text { Quantity } \\
\text { classification }\end{array}$ & $\begin{array}{c}\text { All American } \\
\text { college } \\
\text { students }\end{array}$ & $\begin{array}{c}\text { Number of foreign } \\
\text { students in the } \\
\text { United States }\end{array}$ & $\begin{array}{c}\text { Number of Chinese } \\
\text { students studying in } \\
\text { the United States }\end{array}$ & $\begin{array}{c}\text { Number of students } \\
\text { from other countries in } \\
\text { the United States }\end{array}$ \\
\hline $\begin{array}{l}\text { Quantity } \\
(10,000)\end{array}$ & 1700 & 120 & 33 & 87 \\
\hline
\end{tabular}

According to statistics, the number of foreign students in the United States reached 1.2 million in 2016, accounting for about 8 percent of the total number of college students (17 million) in the United States, of whom 330000 were from China. It accounts for about $30 \%$ of all students studying in the United States. Table 2 and figure 2 .

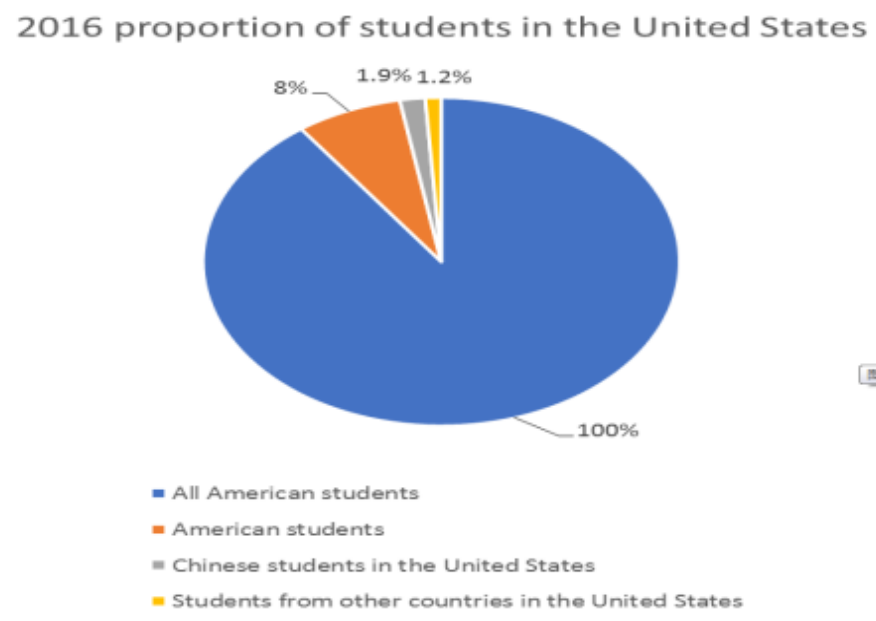

Figure 2. 2016 proportion of American students. 
Zhang, Chen / A study on the Path of internationalization Transformation and Development...

In the process of economic and trade globalization, the internationalization and globalization of higher education play a basic supporting role. A number of internationally renowned, characteristic and high-level institutions of higher learning have been built, and some universities have reached or approached the level of world-class universities, and the international competitiveness of higher education has been significantly enhanced. "Colleges and universities to achieve international well-known, the first is to achieve the internationalization of higher education. It is impossible to build an internationally famous university without internationalization. It is the trend of the times to speed up the internationalization of higher education in China.

\section{Results and Discussion}

\section{Path to internationalization of higher Education}

In the 1980s and 1990s, the internationalization of higher education in China was mainly manifested in students studying abroad (Zeng, Wang \& Lin, 2009), learning advanced experience from western countries, and transferring talents. Since the 21 st century, as our country has gradually increased its influence in the world pattern, In particular, since the "Belt and Road" initiative in 2013, more than 40 countries and international organizations have signed cooperation agreements with China, and Chinese enterprises have invested more than US $\$ 50$ billion in the countries along the route. In 2017, the "Belt and Road" Summit Forum on International Cooperation reached more than 270 cooperative achievements, marking the growing influence of our country in the international community, and our higher education. Internationalization will also change from the mode of international students' output to the pluralistic pattern of students' output and absorption of foreign students.

In 2015, Columbia University, Washington University in St. Louis, University of Southern California, Johns Hopkins University, Carnegie Mellon University, Chinese students accounted for the proportion of all students enrolled in the university, as shown in figure 3 , respectively $12.4 \%$ and $10.8 \%, 9.7 \%$ and $17.2 \%$.

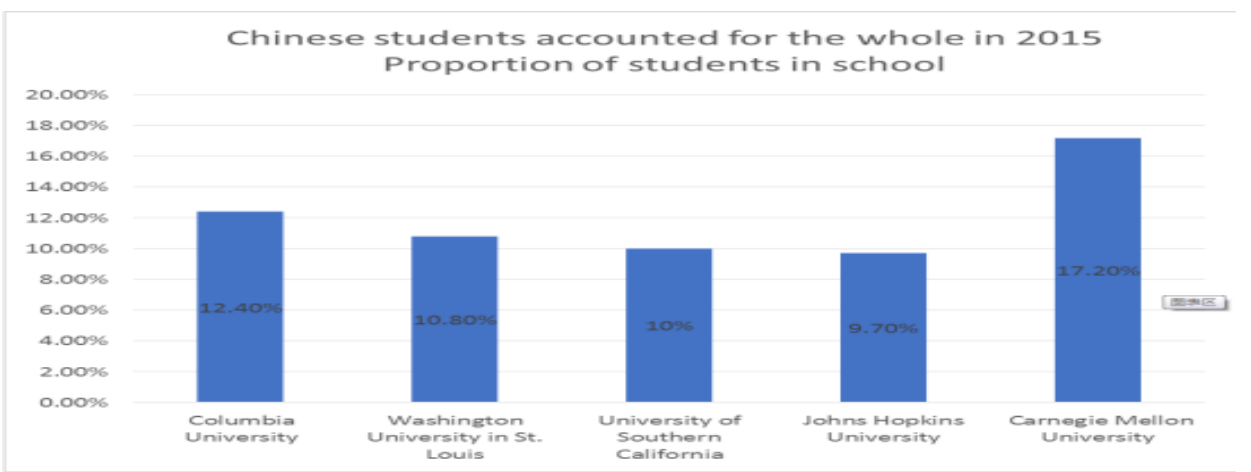

Figure 3. Proportion of Chinese students in school in 2015. 
Zhang, Chen / A study on the Path of internationalization Transformation and Development...

In 2016, the number of college students in our country is as high as 37 million, among which the proportion of foreign students is only 1.18 , the proportion is very low. The gap between the number and proportion of foreign students between China and the United States is huge, and the market space potential of the internationalization of higher education in China is great.

Development of Asian minority language expertise. The vast majority of countries along Belt and Road are emerging markets and developing countries, one of the fastest growing regions in global trade and crossborder investment. (Deng, Zhang \& Li, 2015) In the exchange and cooperation with countries along the route, the first thing to go through is the "language pass." It has been learned that "Belt and Road" covers more than 40 official languages in five regions of Central Asia, Southeast Asia, West Asia and East Africa, but at present, only 20 of them are covered by foreign language majors enrolled in colleges and universities in China. The number of students majoring in minority languages is on the low side. For example, in the "Belt and Road" minority languages, the number of students in 11 languages is less than 100, which is far from enough. To meet the needs of "Belt and Road" construction. The shortage of small language talents has become a bottleneck restricting the implementation of the country's foreign strategy. Colleges and universities should attach importance to the teaching of Asian minority languages and the training of relevant professionals, and add small language courses to the curriculum. It can also be used as a public elective course to enhance students' interest in learning Asian minority languages and understanding Asian culture. For example, Beijing Foreign Studies University, in order to serve the construction of "Belt and Road", actively adjust the specialties of non-universal languages, and add the training of Nepali, Somali, Tamil, Turkmen, Catai, etc. Romanian and other 14 language professionals. The following image shows the total number of foreign language courses offered in 8 universities in Beijing.

Table 3

Proportion of International Understanding Courses in Undergraduate Courses

\begin{tabular}{lcc}
\hline & $\begin{array}{c}\text { International understanding courses in } \\
\text { compulsory / elective courses }\end{array}$ & $\begin{array}{c}\text { Original foreign language teaching material / foreign } \\
\text { language teaching language in professional classes }\end{array}$ \\
\hline D university & $20.0 \% / 6.7 \%$ & $5.0 \% / 5.0 \%$ \\
B university & $11.6 \% / 11.4 \%$ & $-/ 83 \%$ \\
H university & $7.5 \% / 10.8 \%$ & $15.9 \% / 15.9 \%$ \\
A university & $4.2 \% / 3.2 \%$ & $8.2 \% / 6.1 \%$ \\
C university & $3.4 \% / 6.5 \%$ & - \\
F university & $3.2 \% / 1.5 \%$ & $3.8 \% / 1.3 \%$ \\
G university & $0.9 \% / 0.2 \%$ & $0 \% / 0.1 \%$ \\
E university & $1.0 \%-$ & $0.4 \% / 0.3 \%$ \\
\hline
\end{tabular}

\section{The thinking and exploration of the international road of the industry characteristic colleges and universities}

Under the background of "Belt and Road" initiative, colleges and universities of various industries participate in the construction of "Belt and Road" and take the road of internationalization. Take Beijing Printing Institute (hereinafter referred to as Beiyin) as an example, as a prominent industry characteristic of colleges and universities, mainly in the field of printing, packaging and press and publishing. 2016, The total amount of import and export of printing equipment and equipment between China and 64 countries along Belt 
Zhang, Chen / A study on the Path of internationalization Transformation and Development...

and Road is US $\$ 1.24$ billion, accounting for $28 \%$ of the total import and export. Of this total, the total value of exports was 1.026 billion US dollars and the total import value was 214 million US dollars. The export of printing equipment and equipment was far away. More than imports, the total export is four times of the total imports.

In recent years, Bei India has adhered to the concept of "relying on the industry, developing its connotation, giving prominence to its characteristics and opening up its schools". It has established itself in the capital, served the industry, quickened the pace of internationalization, and recruited and trained foreign students along "Belt and Road". The countries along the route of "Belt and Road" have made special training in industry and cooperated in the construction of Confucius Institute. They have made some achievements, and have been approved as the national talent training base of the first batch construction of "Belt and Road" in Beijing. The first is to speed up the training and export of international talents in the printing and packaging industry, and to provide talent support for the printing and packaging enterprises of our country in the areas and countries along the route of "Belt and Road". The cultivation of International talents in Schools It mainly includes two kinds: one is the international printing and packaging industry senior talents who are good at English and know the professional knowledge in the field of printing, focusing on the maintenance, installation, personnel training, after-sales service and so on after the export of the enterprise production line; The other is foreign students from countries and regions along Belt and Road who are familiar with local languages, culture, customs and policies, and solve the problem of localizing the training of professionals.

\section{Process of internationalization of higher education}

The rise of China in the world will speed up the internationalization of higher education in China. Statistics show that China has become the world's largest exporter of overseas students and the largest destination country in Asia. In 2016, the number of students studying in China exceeded 440000, bringing the total number of countries and regions from which students came to China to 205. China has become the largest destination for studying in Asia. In 2016, the number of Chinese studying abroad and returning to China was 544500 and 432500 , respectively, and $80 \%$ of the overseas students chose to return home and develop as shown in Table 4. In the process of globalization, China is the beneficiary and the contributor. The linkage development of China and a large number of other countries has made the global economic development more balanced and provided an important impetus for the development of an open world economy.

Table 4

International students in China and Chinese students in 2016

\begin{tabular}{lcccc}
\hline Classification & $\begin{array}{c}\text { Scale of students } \\
\text { studying in China }\end{array}$ & $\begin{array}{c}\text { Total number of countries } \\
\text { and regions of origin }\end{array}$ & $\begin{array}{c}\text { Chinese students } \\
\text { studying abroad }\end{array}$ & $\begin{array}{c}\text { Returned } \\
\text { students }\end{array}$ \\
\hline Quantity & 440000 & 205 & 544500 & 432500 \\
\hline
\end{tabular}

In recent years, General Secretary Xi Jinping has suggested that international communication should be regarded as the fifth basic function of colleges and universities. This is about colleges and universities. 


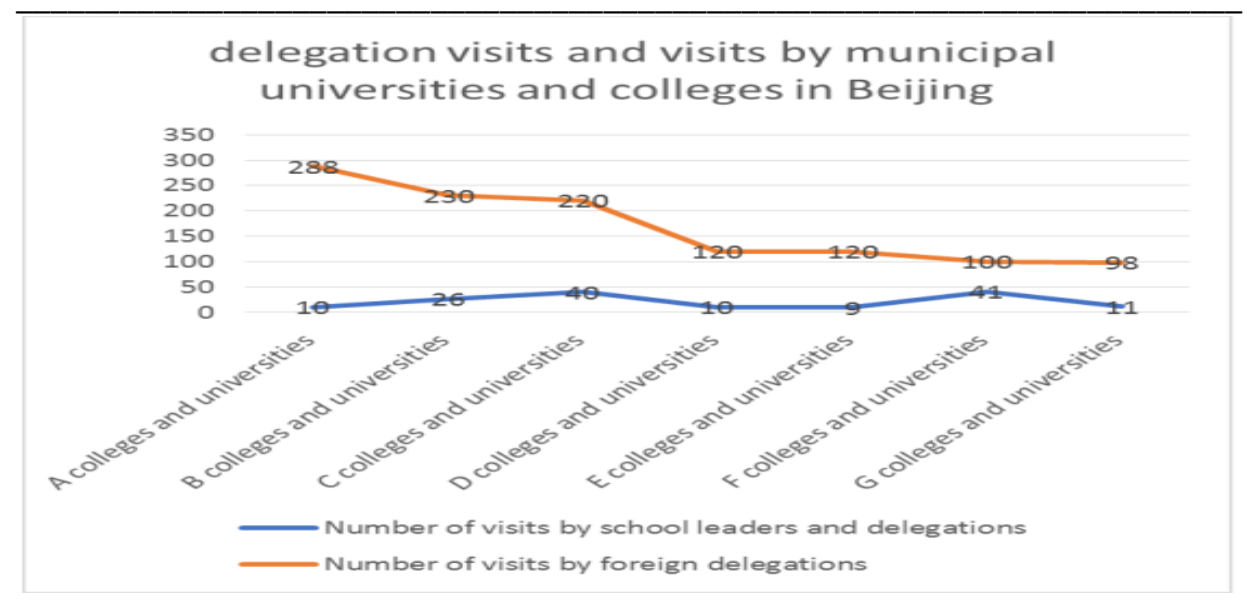

Figure 4. Delegation visits and visits by municipal universities and colleges in Beijing in 2012-2013.

The internationalization road, strengthens our country higher education the international competition ability full affirmation and the positive support. In the process of a country's economic development, talent plays a fundamental, decisive and strategic role. Innovative talents are the essence of human resources. The development and utilization of innovative talent resources is the fundamental driving force to improve the national independent innovation ability, which can greatly improve the utilization and allocation efficiency of production factors. To improve social productivity and production efficiency, promote the sustained, rapid, comprehensive and healthy development of China's regional and overall economy. As a result, colleges and universities play a more prominent role as a base for the cultivation of scientific and technological research and innovative talents. The cultivation of innovative talents in higher education plays an important role in promoting economic productivity and speeding up the pace of economic development in China.

\section{Conclusion}

Italy, Britain, France, Germany and the United States have become the center of higher education in the modern sense. In this process, the development of higher education in the world has always been based on the West, the idea, path and mode of internationalization of higher education has always been based on the western paradigm. With the advantage of higher education center, American-led western countries have gradually become the high-end market of higher education. Although China has become the third largest destination for studying abroad, the quality of foreign students is far behind that of western countries such as the United States. To a certain extent, Western higher education There has been a marked split in the international market. The high-grade international market began to erode the low-grade market. The loss of students, talents and the wealth of the whole country is gradually emerging. (Zeng, Wang \& Lin, 2009) Western values, English language, and western theoretical paradigms have become the necessary conditions for entering the high-level international market. In this environment, the openness, equality and even legitimacy of the internationalization of higher education have been greatly impacted. 
Belt and Road's strategy provides a favorable opportunity for the 2.0 construction of internationalization of higher education. On the one hand, the countries along the route all have the past experience of brain drain, and have a strong desire to improve the existing international pattern of higher education; (Yan, 2016) on the other hand, the political, economic and cultural exchanges between our country and the countries along the route have become increasingly close, and a common market has been initially formed, at the same time, The countries covered by Belt and Road account for about 30 percent of the global economy and 60 percent of the world's population, and (Egret, 2015) have become a key link in the global governance system. Thus, higher Education International The transformation must need the voice of Belt and Road and the voice of China. It is estimated that $85 \%$ of the 73 countries along the route (including key invitation countries) have entered the stage of popularization of higher education. (Zeng, Wang \& Lin, 2009) the strength of higher education has been further strengthened as a whole. Visible, Belt and Road higher education area should play a more important role in the internationalization of higher education. Our government should play a central role in this process.

\section{References}

Deng, C., Zhang, X.C., \& i, C. (2015). A probe into the pattern and path of international talent training in Colleges and Universities under Belt and Road's Strategy: Taking Hainan University as an example. Journal of Hainan Radio and TV University, (4), 107-111. http://dx.doi. org/10.13803 / j. cnki. issn10099743. 201504.024

Egret. (2015). Belt and Road: A probe into the path of strategy leading the internationalization of higher Education. New West, (23), 121-125. http://dx.doi. org/10.3969/j.issn.1009-8607.2015.08.090

Kang, Y.Z. (2008). Historical Evolution and Future trend of higher education financing model in China. HKSAR economy, 235 (8): 258-260. http://dx.doi. org/10.3969/j.issn.1004-0714.2008.08.106

Liu, G. (2012). On the popularization of higher education in China. Journal of Science and Education, (7), 8889. http://dx.doi. org/10.3969/j.issn.1674-6813.2012.07.048.

Philip, G., Atbach, J. W. (2006). Prospect of internationalization of higher Education: Motivation and reality. Higher Education Studies, (1),12-21. http://dx.doi. org/CNKI:SUN:HIGH.0.2006--01-002.

Qin, S.J., Xia, G.E. (2016). On the internationalization cooperation of higher education between China and ASEAN under the background of belt and road. Economic and Social Development, 14 (6), 85-88 http://dx.doi. org/10.16523/j.45-1319.2016.06.019.

Wu, C., Hong, C.W. (2013). On the Transformation of higher education development mode in China based on the perspective of development economics. Modern Education Management, (7), 11-16. http://dx.doi. org/10.3969/j.issn.1674-5485.2013.07.003 
Zhang, Chen / A study on the Path of internationalization Transformation and Development...

$\overline{\mathrm{Xu}, \text { H., \& Huang, H. (2016). A study on the internationalization path of higher vocational education under the }}$ strategic background of belt and road. Jiangsu higher Education, 188 (4), 143-145. http://dx.doi. org/ 10.13236J.cnki.jshe.2016.04.039

Yan, J.Y. (2016). A study on the internationalization development strategy of higher education in China under the Strategy of belt and road. Decision-making and Information, (4). http://dx.doi. org/10.3969/j.issn.1002-8129.2016.04.013

Zeng, M.C., Wang, M.X., \& in, L. (2009). Internationalization of higher education in the United States, Britain and Australia. Peking University Education Review, (2), 75-103. http://dx.doi. org/10.3969/j.issn.1671-9468.2009.02.007 